\title{
18 Chemical and Physical Factors Influencing Toxin Content
}

\author{
E. GranÉLI and K. FlynN
}

\subsection{Introduction}

Many isolates of the same species display qualitatively similar toxin profiles supporting the view that toxin production is heritable, at least for PSP toxin producers (see Cembella and John, Chap. 17). It is not known, however, why some phytoplankton species produce toxins while most do not, or perhaps more perplexing, why some strains of the same species are toxic while others are not. One may expect that if it were advantageous, all strains of the same species would display similar levels of toxicity and they may also be expected to be toxic most of the time. It is even possible that at least some algae do not produce toxins themselves, but that toxin production is caused by intracellular bacteria (Kodama 1990, cited in Granéli et al. 1998, see also Chap. 19). Toxin production can also be stimulated by the presence of grazers (Pohnert et al. 2002).

Algal toxins are secondary metabolites that vary in structure, atomic composition, and functional activity. Thus, it is not surprising that factors stimulating toxin production in one algal species/group may have a different impact on another. This chapter considers the factors affecting the accumulation of toxins. In Chap. 17, Cembella and John consider this topic at the molecular and genetic level, and phase of cell cycle, while here we focus on interactions between the growth stage (lag, exponential and stationary phases) and physico-chemical environmental factors.

\subsection{Growth Stage and Toxin Production}

In general, changes in toxin content are associated with disturbed (unbalanced) physiology, with the up-shock or down-shock of cells exiting or 
entering stationary phases (Anderson 1994; Flynn et al. 1994, 1996; Johansson and Granéli 1999a, 1999b; Granéli et al. 1998; Edvardsen et al. 1990, cited in Granéli et al. 1998). Toxin production in normal experiments can be difficult to measure against a background of changing cell biomass, cell size and indeed toxin leakage or catabolism. Thus changes in toxin content per cell may simply reflect changes in cell size accompanying changes in nutrient status, temperature, or salinity. For this reason, here we have usually referred to changes in toxin content, rather than specifically to changes in production. Nonetheless, depending on the chemical composition of the toxin, different treatments may be expected to have different impacts. Thus $\mathrm{N}$-rich PSP-toxins are synthesized during N-upshock and P-stress (which gives relatively high $\mathrm{N}$-status) and not during N-downshock (Flynn et al. 1994; Granéli et al. 1998).

Table 18.1 illustrates the importance of up/down shock events in affecting toxicity. Thus, domoic acid (DA) has been shown to be produced primarily in stationary phase, with little or none in exponential phase, in several strains of Pseudo-nitzschia multiseries (Pan et al. 1996a, 1996 c, cited in Bates 1998). If toxin-containing cells from the late stationary phase are re-inoculated into fresh, nutrient-replete medium, cellular DA levels decrease as cells re-enter exponential phase (Douglas et al. 1993, cited in Bates 1998); the existing toxin produced during the stationary phase becomes more and more diluted by division of the exponentially growing cells. PSP content in the freshwater cyanobacterium Anabaena circinalis is highest in stationary phase (Negri et al. 1997) similar to the pattern of $P$. multiseries DA toxin production. The dinoflagellate Prorocentrum minimum is toxic only sporadically, but a higher toxicity always occurs when the cells are in the declining phase of the growth cycle (Wikfors 2005). Construction of models describing such activity helps us understand these conflicting and at times counter-intuitive processes (John and Flynn 2002; Flynn 2002a), but very few experiments yield suitable data sets for modeling.

\subsection{Physical Factors Influencing Toxin Content}

Low temperature decreased the growth rate of the PSP-producing dinoflagellates Alexandrium catenella, A. cohorticula and Gymnodinium catenatum, whereas it increased toxin content per cell (Ogata et al. 1989, cited in Granéli et al. 1998). In contrast, a low growth rate due to light inhibition did not cause an increase in toxin content, compared to cells growing at optimum illumination. Salinity had a greater effect on toxin production than did temperature, for the prymnesiophyte Chrysochromulina polylepis (Anderson 1994). The raphidophyte Fibrocapsa japonica strongly increased its hemolytic activity at low salinities (de Boer et al. 2004). Flynn et al. (1996) suggested that salinity 
may influence PSP toxin synthesis by affecting the distribution of metabolites toward osmotic regulation.

Toxin production in marine and freshwater cyanobacteria species has also been shown to be affected by temperature (e.g., Sivonen 1990; Lehtimäki et al. 1994), illumination (e.g., Sivonen 1990) and salinity (Lehtimäki et al. 1994). High pH can induce higher toxicity in Chrysochromulina polylepis and Oscillatoria laetevirens (Ray and Bagchi 2001; Schmidt and Hansen 2001). This has also been suggested to be the case for Pseudo-nitzschia species and Nitzschia navis-varingica (Lundholm et al.2004).

A major problem with all these studies is that as cell size varies with physical environmental changes, toxin per cell will obviously vary to some extent. Many physical and biological factors also interact, promoting increases in toxicity for different phytoplankton species and toxin groups in different ways. $\mathrm{pH}$ will inevitably change during consumption of nutrients. Thus, a link between $\mathrm{pH}$ and toxin content may not be a cause, but an effect. Quite likely these interactions will also be synergistic. Flynn (2002a) simulated the synergistic impacts of nutrient stress, nutrient refeeding, and variable illumination encountered by vertically migrating Alexandrium; the combined impacts on toxin production exceeded those of single factors.

\subsection{Inorganic Nutrients and Toxin Content}

Changes in the relative and absolute discharges of phosphorus $(\mathrm{P})$ and silicon $(\mathrm{Si})$, and especially the increases of nitrogen $(\mathrm{N})$ entering coastal waters, are not in balance with the demands from algae (Conley 1999). The extent to which changes in nutrient concentrations and ratios are linked to toxic/harmful phytoplankton blooms and their toxin production is poorly understood and highly controversial. These changed ratios affect not only algal physiology but also the structure of phytoplankton communities (Smayda 1997). Stress caused by rate limitation of these nutrients differs greatly. Si stress, which directly affects only diatoms and silicoflagellates, prevents cell division while not directly affecting carbon, nitrogen and phosphorus (CNP) physiology. $\mathrm{N}$ stress impacts primarily on somatic growth. $\mathrm{P}$ stress, however, has the potential for not only affecting growth but also for having numerous insidious effects through disturbing metabolic regulation; phosphorylation of intermediates is the most common form of biochemical regulation. That $\mathrm{P}$ stress should impact so frequently on the production of toxins is thus not surprising (Table 18.1). Neither is it surprising that these nutrient-stress should interact.

Phosphorus deficiency has been shown to increase PSP toxin levels 3- to 4fold in Alexandrium tamarense in comparison to nutrient-sufficient or $\mathrm{N}$ deficient cells (Boyer et al. 1987, cited in Cembella 1998). Also, the dinoflagel- 
late G. catenatum has been shown to increase its intracellular toxin concentration under P deficiency (Boyer et al. 1987, cited in Cembella 1998; Flynn et al. 1996). Synthesis of N-containing toxins (such as DA and PSP) declines under N stress (Bates et al. 1991, cited in Bates 1998; Boyer et al. 1987, cited in Cembella 1998), and increases after reintroduction of N (Bates et al. 1991, cited in Bates 1998; Flynn et al. 1994). Toxin content in A. excavatum (Levasseur et al. 1995, cited in Granéli et al. 1998) and P. multiseries (Bates et al. 1993, cited in Bates 1998) has also been shown to increase when $\mathrm{N}$ is available in high concentration, but even more so if ammonium is used as a $\mathrm{N}$ source rather than nitrate (Levasseur et al. 1995, cited in Granéli et al. 1998).

Si-limited growth of Pseudo-nitzschia promotes synthesis of DA (a nonprotein amino acid). For the pennate diatom $P$. multiseries, DA production is triggered by silicate $(\mathrm{Si})$ and/or phosphate $(\mathrm{P})$ limitation (Bates et al. 1991 and Pan et al. 1996a, 1996 c, cited in Bates 1998; Pan et al. 1998). By successively adding back these two limiting nutrients, Pan et al. 1996a, 1996 c, cited in Bates 1998) were able to gradually decrease DA production as stress decreased. The increase in the production of DA under such conditions is favored because, when primary metabolic activity is decreased, necessary precursors, as well as high energy compounds and several co-factors are made available (Pan et al. 1998). Toxic blooms of $P$. multiseries have been associated with nitrate pulses (Smith et al. 1990, cited in Granéli et al. 1998). Bates et al. (1993, cited in Bates 1998) found that this species required a high concentration of nitrate to produce DA. The toxin content of the cells increased from $0.2-5$ pg DA cell ${ }^{-1}$ when nitrate in the growth medium was increased from 55 to $880 \mu \mathrm{M}$ and inorganic $\mathrm{P}$ was held constant at $33 \mu \mathrm{M}$. Whether the impact of N:P supply is due to different levels of N-P stress, or to the 'forced' entry of nitrate through a second nitrate transporter that operates only at high nitrate concentrations (see Flynn 2001) is not known.

In the cyanobacterium Nodularia spumigena, toxin production increases under P limitation. Stolte et al. (2002) grew N. spumigena under P limitation but with different sources of $\mathrm{N}$ (nitrate, ammonium and $\mathrm{N}_{2}$-fixation); nitrate addition produced the highest amounts of biomass (chlorophyll- $a$ ) and nodularin. However, similar amounts of nodularin per amount of chlorophyll or carbon were produced during the stationary phase, independent of the addition of ammonium or nitrate. In contrast, the freshwater cyanobacterium Oscillatoria agardhii has been shown to increase toxin production proportionally to the increase of $\mathrm{N}$ in the medium (Sivonen 1990). Phosphorus concentrations of between 12.9 and $177 \mu \mathrm{M}$ had no effect on toxin production, and concentrations below $3.3 \mu \mathrm{M}$ could not support good toxin production (Sivonen 1990). In Microcystis aeruginosa removal of $\mathrm{N}$ from the medium correlated with the amount of microcystin synthesized (Orr and Jones 1998). Thus the same pattern of toxin production is seen in cyanobacteria as for the dinoflagellates mentioned previously; the cellular $\mathrm{N}$ status correlates with toxin content or production. 
For the above groups of organisms under $\mathrm{P}$ limitation, the availability of nitrogenous compounds within the cell increases relative to cells grown under $\mathrm{N}$ limitation while cellular regulation controlling synthesis and growth slows or ceases. Accordingly, secondary metabolites accumulate and some of these are what we describe as toxins. Cells under different levels of $\mathrm{N}$ stress (deficiency) will have lower synthesis rates of secondary metabolites; strain and species differences in physiology will affect the balance between toxin synthesis and cell growth, which together affect the net rate of accumulation of toxin within the cell (Fig. 18.1). Because the availability of nutrients within the cell establishes the degree of nutrient stress, levels of illumination will affect $\mathrm{C}$ fixation and energy production, interacting with nutrient availability to set these levels of stress. The net rate of accumulation of toxins will also vary. For example, Flynn et al. (1994) found that neither short-term N nor P limitation promoted toxin increase in A. minutum cells whereas Guisande et al. (2002) showed an increase in toxin content when the same organism was grown under P limitation (see also Fig. 18.1). For A. fundyense N:P supply ratios did also affect toxin production (John and Flynn 2000) until nutrient exhaustion occurred.

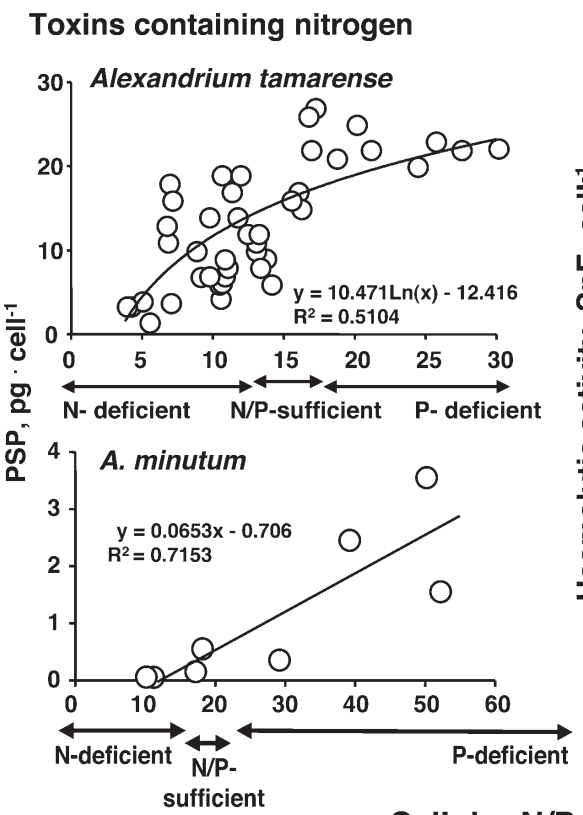

\section{Toxins containing little or no nitrogen}

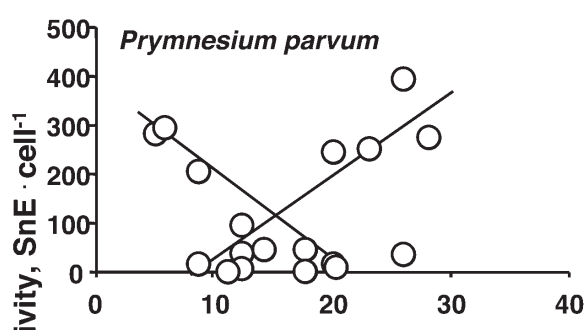

Cellular N/P-ratios (atoms)

Fig. 18.1. Relation between intracellular nitrogen and phosphorus ratios and toxin concentrations for the toxin-producing dinoflagellates Alexandrium tamarense and A. minutum (data from the NUTOX project, see Acknowledgements) and flagellates Prymnesium parvum and Chrysochromulina polylepis grown under different $\mathrm{N}$ and $\mathrm{P}$ conditions (data from Johansson and Granéli 1999a, 1999b) 
For diarrhetic shellfish poisoning (DSP)-producing Prorocentrum lima, both $\mathrm{N}$ and $\mathrm{P}$ deficiency have been found to promote high okadaic acid (OA) toxin accumulations (McLachlan et al. 1994 and Sohet et al. 1995, cited in Granéli et al. 1998). For Dinophysis species, Johansson et al. (1996) have shown that under $\mathrm{N}$ limitation, OA levels in D. acuminata cells increased (from 9 to 23 pg OA cell-1), whereas in D. acuta there was an increase in OA only when the cells were grown in sufficient conditions with a N:P atomic ratio of 16:1. Under the same NP-sufficient conditions, $D$. acuta cells had high quantities of dinophysistoxin-1, whereas the DTX-1 content of D. acuminata was close to the analytical detection limit, independent of nutrient conditions.

For ichthyotoxic harmful algal species, it seems more the rule that limitation by either $\mathrm{N}$ or $\mathrm{P}$ increases toxin content (Fig. 18.1). The prymnesiophyte Chrysochromulina polylepis growing in a medium with a high $\mathrm{N}: \mathrm{P}$ ratio increased its toxin content (Edvardsen et al. 1990, cited in Granéli et al. 1998; Johansson and Granéli 1999b). This may appear somewhat surprising considering that (so far) the only identified C. polylepis toxin is a N-poor compound; the implication is that disturbed physiology under $\mathrm{P}$ stress, rather than a surplus of $\mathrm{N}$, is the trigger (noting that nitrate-grown cells are by definition more N stressed than ammonium-grown cells; Flynn 2001).

The prymnesiophyte Prymnesium parvum increased its toxin content under either $\mathrm{N}$ - or P-limited steady-state conditions, although toxin content was more accentuated under the latter (Fig. 18.1) (Johansson and Granéli 1999a). Similar results were also found by (Edvardsen et al. 1990, cited in Granéli et al. 1998) for C. polylepis growing in semi-continuous cultures; both $\mathrm{P}$ and $\mathrm{N}$ limitation increased intracellular toxin concentration in this flagellate. However, several other species and strains of Chrysochromulina sp. were tested and found not to contain high (if any) amounts of toxin under P-limiting conditions (Edvardsen 1993, cited in Granéli et al. 1998). Chrysochromulina leadbeateri cells were only slightly toxic under P limitation, whereas this species had been shown to be extremely toxic in the field, when it bloomed in northern Norway during May-June 1991, causing the death of tons of caged fish (Edvardsen 1993, cited in Granéli et al. 1998). Why this species did not produce high quantities of toxin in experiments might be explained by differences in the species strain and/or by differences in the nutrient concentration as well as its N:P (Edvardsen 1993, cited in Granéli et al. 1998). It should also be noted that a high $\mathrm{N}: \mathrm{P}$ ratio at low ambient $\mathrm{N}$ concentrations will not cause the same level of $\mathrm{P}$ stress to a cell as will the same ratio at high $\mathrm{N}$ concentrations; in the former, dual ( $\mathrm{N}$ and $\mathrm{P}$ ) rate limitation will occur.

Thus, there is a group of phytoplankton species that can increase cellular toxin concentrations when grown under $\mathrm{N}$ - or P-deficiency. Both conditions will result in an imbalanced production of $\mathrm{C}$ metabolites. A dual limitation, however, will result in a rapid deregulation of $\mathrm{C}$ metabolism; toxin production under such conditions may be expected to be low. The low $\mathrm{N}$ and $\mathrm{P}$ threshold 


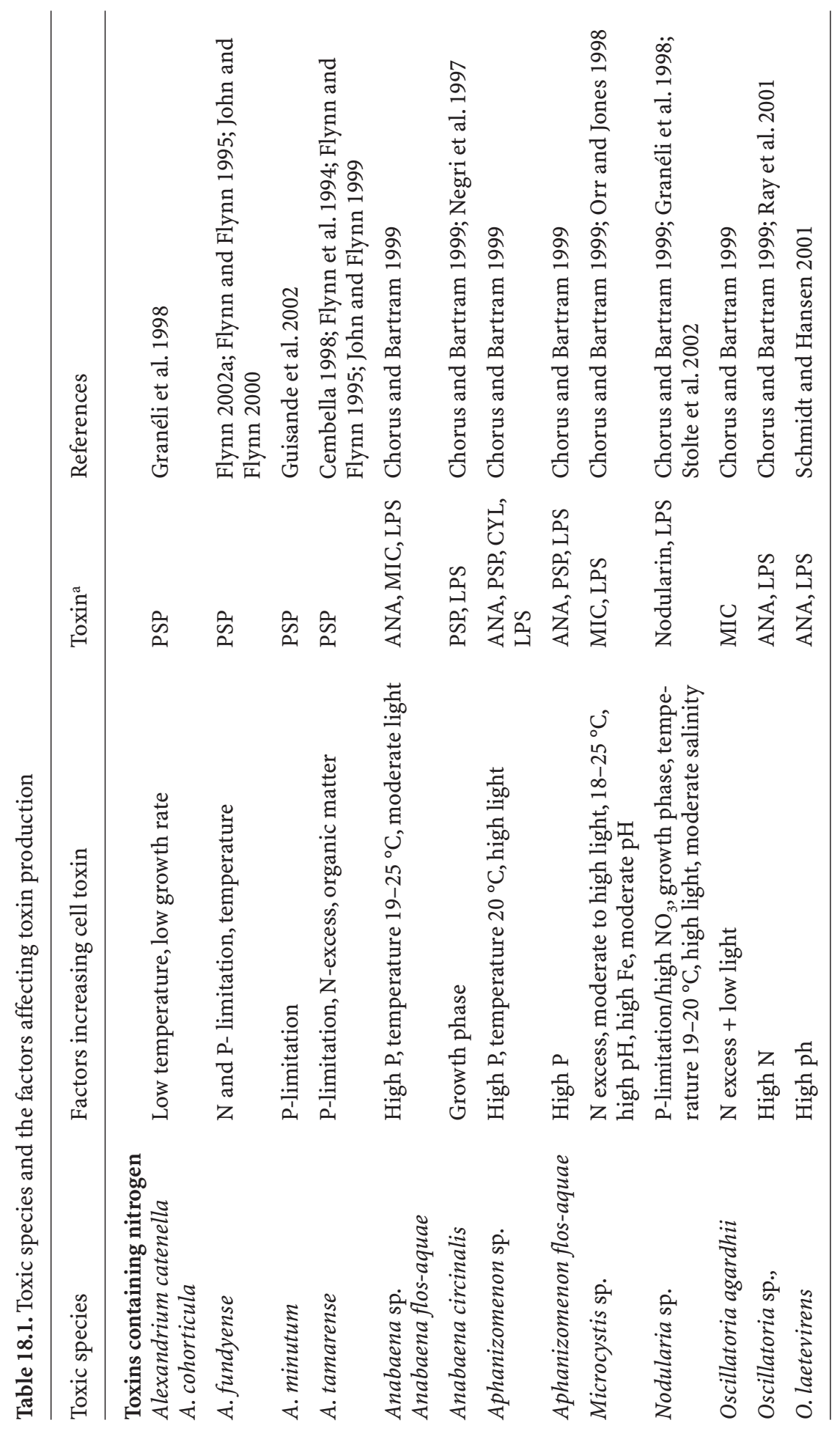


E. Granéli and K. Flynn

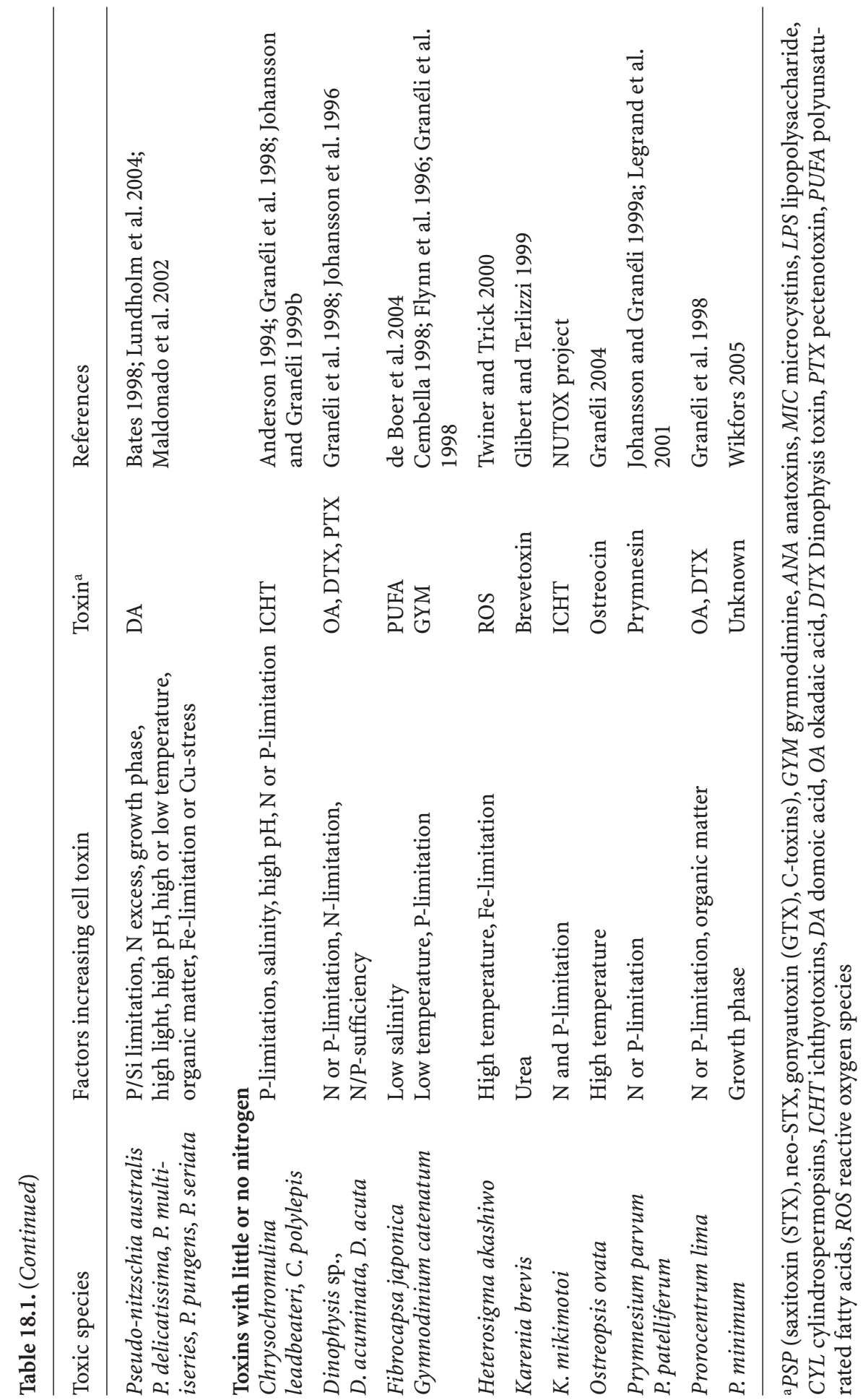


concentrations that cause toxin levels to increase can only be achieved in waters where these nutrients are found in imbalanced conditions i.e., where $\mathrm{N}: \mathrm{P}$ ratios are under or above 16 .

Figure 18.1 and Table 18.1 summarize the evidence for the impact of environmental and nutrient availability on toxin production. It is important to appreciate that nutrient supply ratios are only part of the story. The impact of $\mathrm{N}: \mathrm{P}$ ratios (for example) on algal growth and nutrient stress will depend greatly on the residual nutrient concentration in the seawater. Unfortunately, many studies of algal physiology have not considered the impact of such events, and models of algal physiology are usually poorly configured to reflect the interaction (Flynn 2001, 2002b). Further, while steady-state (discontinuous or chemostat) cultures may be favored for use by experimentalists, they do not reflect the dynamic situation in nature, which has the potential for significantly changing secondary- metabolite and toxin-production patterns (e.g., Flynn 2002a). The only nutrient levels and ratios that ultimately matter are internal, not external. Thus, interpretation of studies without cellular $\mathrm{C}: \mathrm{N}: \mathrm{P}(: \mathrm{Si})$ ratios plus concurrent $\mathrm{C}$-specific growth determination and $\mathrm{C}$-specific toxin content is difficult and potentially misleading.

\subsection{Organic Matter and Toxin Content}

Organic matter can affect the production of several toxins in different ways. Care must be taken in interpreting the ecological significance of some studies. While the uptake of organic nutrients at natural concentrations has been demonstrated (e.g., amino acids by Alexandrium; John and Flynn 1999), the impacts of substrates applied at concentrations orders-of-magnitude greater than those in nature, while perhaps demonstrating important biochemical pathways, may be of little or no ecological consequence.

The diatom P. multiseries has been shown to increase its DA content when grown with a mixture of gluconic acid/gluconolactone (produced by the bacterium Alteromonas sp., or added directly) (Osada and Stewart 1997, cited in Bates 1998). While A. tamarense decreases PSP toxin content under N limitation, it can increase it if yeast is added to the cultures (Ogata et al. 1996, cited in Cembella 1998); the implication is that this species can use organic nitrogen. Gymnodinium breve can increase brevetoxin content by up to six times when grown with urea at 0.5 to $1.0 \mathrm{mM}$ nitrogen (cited in Glibert and Terlizzi 1999).

Very little is known about the connection between other forms of algal nutrition, e.g., ingestion of dissolved organic material (DOM) or particles (mixotrophy), and toxin production. Okadaic acid concentrations in P. lima cells were higher when organic P (glycerol) was supplied instead of inorganic $P$ to the growth medium (Tomas and Baden 1993, cited in Granéli et 
al. 1998). However, Sohet et al. (1995, cited in Granéli et al. 1998) could not find a correlation between organic $\mathrm{P}$ or humic acid addition and the toxin content of P. lima. Phosphorus-limited N. spumigena cells growing in media containing additional humic substances produced half as much toxin as did P-limited cultures; the implication is that humics were a source of $\mathrm{P}$, although this was not sufficient to decrease toxin content to the same low levels as found in the cultures growing under nutrient-balanced conditions (Granéli et al. 1998).

Okadaic acid content in D. acuminata correlates with the occurrence of inclusion bodies in cells under $\mathrm{N}$-deficient conditions. It was not possible, however, to determine if the higher toxin levels found in the N-deficient treatment were associated directly with phagotrophy or with nutrient deficiency per se; nutrient deficiency may have triggered phagotrophy. For the haptophyte Prymnesium parvum, high toxin levels resulting from $\mathrm{P}$ deficiency decreased after the cells ingested bacteria; presumably the bacteria provided the missing P (Legrand et al. 2001). Thus, the hypothesis of toxin accumulation by active ingestion of these bacteria, in this case, can be ruled out.

\subsection{Conclusions}

There is a wide variation, not only between algal groups but also species and strains, with respect to their toxin-content response to different nutrient conditions. Phosphorus limitation often seems to enhance cellular toxin content. $\mathrm{N}$ limitation does so to a lesser extent, or may, in the cases of DA and PSP, do the opposite and lead to a fall in toxin content. In most instances, toxin content is relatively low under nutrient-balanced conditions $(\mathrm{N}: \mathrm{P} \sim 16: 1)$. Thus, it seems that physiological stress, rather than solely $\mathrm{P}$ or $\mathrm{N}$ limitation, can be associated with an increase in toxin content. However, because carbon fixation requires significant investment in terms of $\mathrm{N}$ - and P-containing compounds, even here, some interaction may be expected, depending on the timescale of stress induction.

A major problem in HAB research, in general, is the reliance on cell number as the basis for describing toxin content. Because cell size also varies with changes in environmental conditions such as temperature and light, it becomes less clear whether toxin production per se alters with these conditions. Biomass $[\mathrm{CNP}(\mathrm{Si})]$ determinations, indicating the internal nutrient status, are also necessary for an improved interpretation of the results. Further, in the absence of $\mathrm{CNP}(\mathrm{Si})$ data, most studies are also woefully inadequate for supporting modeling efforts. It is therefore not possible to unequivocally identify definitive common causal relationships between stressors (physical and/or nutrient) and toxin production.

Toxin accumulation occurs primarily under unbalanced-nutrient condi- 
tions, and when cells are not growing optimally. This suggests that production is only sometimes advantageous, even though production costs appear minor (John and Flynn 2002). If it were of universal value then one would expect toxin production to be common and to occur during normal exponential growth. This limited functionality, essentially being selection-neutral, may explain why toxin production ability varies so greatly among and within species and strains. However, it is quite likely that in both harmful algae and other phytoplankton, many other secondary metabolites are also produced that is at the least indigestible (if not unpalatable) to grazers thus affecting predator-prey interactions. Our understanding of what promotes toxin production in harmful algae has important ramifications for our general understanding of phytoplankton ecophysiology.

Acknowledgements. Edna Granéli thanks Christina Esplund-Lindquist for preparing the figures and tables and Roseni Carvalho for the reference list. Thanks to the Swedish Natural Research Council and the European Commission MAST-NUTOX (contract nr: MAS-3-CT97-0103) and FP 6, THRESHOLDS projects (contract nr: GOCE 003933) for financial support to EG. Kevin Flynn was supported by the Royal Society/Leverhulme Trust, and by the Natural Environment Research Council (UK).

\section{References}

Anderson DM (1994) Red tides. Sci Am 271:52-58

Bates SS (1998) Ecophysiology and metabolism of ASP toxin production. In: Anderson DM, Cembella AD, Hallegraeff GM (eds) Physiological ecology of harmful algal blooms. NATO ASI Series 41. Springer, Berlin Heidelberg New York, pp 405-426

Cembella AD (1998) Ecophysiology and metabolism of paralytic shellfish toxins in marine microalgae. In: Anderson DM, Cembella AD, Hallegraeff GM (eds) Physiological ecology of harmful algal blooms. NATO ASI Series 41. Springer, Berlin Heidelberg New York, pp 381-403

Chorus I, Bartram J (eds) (1999) Toxic cyanobacteria in water: a guide to their public health consequences, monitoring and management. (c) 1999, WHO http://www. who.int/docstore/water_sanitation_health/toxicyanobact/begin.htm\#Contents

Conley DJ (1999) Biogeochemical nutrient cycles and nutrient management strategies. Hydrobiologia 410:87-96

de Boer MK, Tyl MR, Vrieling EG, van Rijssel M (2004) Effects of salinity and nutrient conditions on growth and haemolytic activity of Fibrocapsa japonica (Raphidophyceae). Aquat Microb Ecol 37:171-181

Flynn KJ (2001) A mechanistic model for describing dynamic multi-nutrient, light, temperature interactions in phytoplankton. J Plankton Res 23:977-997

Flynn KJ (2002a) Toxin production in migrating dinoflagellates: a modelling study of PSP producing Alexandrium. Harmful Algae 1:147-155

Flynn KJ (2002b) How critical is the critical N:P ratio? J Phycol 38:961-970

Flynn KJ, Flynn K (1995) Dinoflagellate physiology, nutrient stress and toxicity. In: Lassus P, Arzul G, Le Denn EE, Gentien P, Marcaillou C (eds) Harmful marine algal blooms. Lavoisier Intercept, Paris, pp 541-550 
Flynn K, Franco JM, Fernández P, Reguera B, Zapata M, Wood G, Flynn KJ (1994) Changes in toxin content, biomass and pigments of the dinoflagellate Alexandrium minutum during nitrogen refeeding and growth into nitrogen and phosphorus stress. Mar Ecol Prog Ser 111:99-109

Flynn KJ, Flynn K, John EH, Reguera B, Reyero MI, Franco JM (1996) Changes in toxins, intracellular and dissolved free amino acids of the toxic dinoflagellate Gymnodinium catenatum in response to changes in inorganic nutrients and salinity. J Plankton Res 18:2093-2111

Glibert PM, Terlizzi DE (1999) Co-occurrence of elevated urea levels and dinoflagellate blooms in temperature estuarine aquaculture ponds. Appl Environ Microbiol 65:5594-5596

Granéli E (2004) Toxic algae - a global problem. HavsUtsikt 2:12-13 (in Swedish)

Granéli E, Johansson N, Panosso R (1998) Cellular toxin contents in relation to nutrient conditions for different groups of phycotoxins. In: Reguera B, Blanco J, Fernandez ML, Wyatt T (eds) Harmful algae. Xunta de Galicia and IOC-UNESCO, Grafisant, Santiago de Compostela, Spain, pp 321-324

Guisande C, Frangópulos M, Maneiro I, Vergara AR, Isabel Riveiro I (2002) Ecological advantages of toxin production by the dinoflagellate Alexandrium minutum under phosphorus limitation Mar Ecol Prog Ser 225:169-176

Johansson N, Granéli E (1999a) Influence of different nutrient conditions on cell density, chemical composition and toxicity of Prymnesium parvum (Haptophyta) in semicontinuous cultures. J Exp Mar Biol Ecol 239:243-258

Johansson N, Granéli E (1999b) Cell density, chemical composition and toxicity of Chrysochromulina polylepis (Haptophyta) in relation to different N:P supply ratios. Mar Biol 135:209-217

Johansson N, Granéli E, Yasumoto T, Carlsson P, Legrand C (1996) Toxin production by Dinophysis acuminata and D. acuta cells grown under nutrient sufficient and deficient conditions. In: Yasumoto T, Oshima Y, Fukuyo Y (eds) Harmful and toxic algal blooms. IOC-UNESCO, Paris, pp 277-280

John EH, Flynn KJ (1999) Amino acid uptake by the toxic dinoflagellate Alexandrium fundyense. Mar Biol 133:11-20

John EH, Flynn KJ (2000) Growth dynamics and toxicity of Alexandrium fundyense (Dinophyceae): the effect of changing N:P supply ratios on internal toxin and nutrient levels. Eur J Phycol 35:11-23

John EH, Flynn KJ (2002) Modelling changes in paralytic shellfish toxin content of dinoflagellates in response to nitrogen and phosphorus supply. Mar Ecol Prog Ser 225:147-160

Legrand C, Johansson N, Johnsen G, Borsheim KY, Granéli E (2001) Phagotrophy and toxicity variation in the mixotrophic Prymnesium patelliferum (Haptophyceae). Limnol Oceanogr 46:1208-1214

Lehtimäki J, Sivonen K, Luukkainen R, Niemela SI (1994) The effects of incubation-time, temperature, light, salinity, and phosphorus on growth and hepatotoxin production by Nodularia strains. Arch Hydrobiol 130:269-282

Lundholm N, Hansen PJ, Kotaki Y (2004) Effect of pH on growth and domoic acid production by potentially toxic diatoms of the genera Pseudo-nitzschia and Nitzschia. Mar Ecol Prog Ser 273:1-15

Maldonado MT, Hughes MP, Rue EL, Wells ML (2002) The effect of Fe and Cu on growth and domoic acid production by Pseudo-nitzschia multiseries and Pseudo-nitzschia australis. Limnol Oceanogr 47:515-526

McLachlan JI, Marr JC, Conolon-Kelly A, Adamson A (1994) Effects of nitrogen concentration and cold temperature on DSP-toxin concentration in the dinoflagellate Prorocentrum lima (Prorocentrales, Dinophyceae). Natural Toxins 2:263-270 
Negri AP, Jones GJ, Blackburn SI, Oshima Y, Onodera H (1997) Effect of culture and bloom development and of sample storage on paralytic shellfish poisons in the cyanobacterium Anabaena circinalis. J Phycol 33:26-35

NUTOX project European Commission MAST-NUTOX (contract nr: MAS-3-CT97-0103)

Orr PT, Jones GJ (1998) Relationship between microcystin production and cell division rates in nitrogen-limited Microcystis aeruginosa cultures. Limnol Oceanogr 43:1604-1614

Pan Y, Bates SS, Cembella, AD (1998) Environmental stress and domoic acid production by Pseudo-nitzschia: a physiological perspective. Natural Toxins 6:127-135

Pohnert G, Lumineau O, Cueff A, Adolph S Codevant C, Lang M, Poulet S (2002) Are volatile unsaturated aldehydes from diatoms the main line of chemical defence against copepods? Mar Ecol Prog Ser 245:33-45

Ray S, Bagchi SN (2001) Nutrients and pH regulate algicide accumulation in cultures of the cyanobacterium Oscillatoria laetevirens. New Phytol 149:455-460

Schmidt LE, Hansen PJ (2001) Allelopathy in the prymnesiophyte Chrysochromulina polylepis: effect of cell concentration, growth phase and $\mathrm{pH}$. Mar Ecol Prog Ser 216:67-81

Sivonen K (1990) Effects of light, temperature, nitrate, orthophosphate, and bacteria on growth of and hepatotoxin production by Oscillatoria agardhii strains. Appl Environ Microbiol 56:2658-2666

Smayda TJ (1997) Harmful algal blooms: their ecophysiology and general relevance to phytoplankton blooms in the sea. Limnol Oceanogr 42:1137-1153

Sohet K, Pereira A, Braeckman JC, Houvenaghel G (1995) Growth and toxicity of Prorocentrum lima (Ehrenberg) Dodge in different culture media: effects of humic acids and organic phosphorus. In: Lassus P, Arzul G, Le Denn EE, Gentien P, Marcaillou C (eds) Harmful marine algal blooms. Lavoisier Intercept Paris, pp 669-674

Stolte W, Karlsson C, Carlsson P, Granéli E (2002) Modeling the increase of nodularin content in Baltic Sea Nodularia spumigena during stationary phase in phosphoruslimited batch cultures. FEMS Microbiol Ecol 41:211-220

Twiner MJ, Trick CG (2000) Possible physiological mechanisms for production of hydrogen peroxide by the ichthyotoxic flagellate Heterosigma akashiwo. J Plankton Res 22:1961-1975

Wikfors GH (2005) A review and new analysis of trophic interactions between Prorocentrum minimum and clams, scallops, and oysters. Harmful Algae 4:585-592 
